\title{
Melatih Anggota Keltan Rambutan dan Keltan Sakato Kota Padang untuk Mengendalikan Wereng Batang Coklat (WBC) dengan Joint Predator
}

\author{
Sandra Desiska, My Syahrawati, Arneti, Zurai Resti, Martinius, Haliatur Rahma, Eri \\ Sulyanti, Tre Julia Nasral, dan Ryan Hidayat \\ Fakultas Pertanian, Universitas Andalas, Kampus Limau Manis, Padang, 25163. Indonesia \\ E-mail: mysyahrawati@agr.unand.ac.id
}

Keywords: competition, lady beetle, wolf spider, predator

Kata Kunci: kompetisi, kumbang bemo, laba-laba serigala, predator

\begin{abstract}
The attacks of brown planthopper or BPH (Nilaparvata lugens) in West Sumatra have been recorded since 2012 and continued to increase throughout 2015-2017. Wolf spider (Pardosa pseudoannulata) and lady beetle (Verania lineata) are two predators that can be used as natural enemies. Some research reports that the wolf spider can consume the BPH as much as 5-15 individuals while lady beetles consume as much as 111 individuals per day. Training on the use of two predators was carried out in farmer group of Rambutan, Kelurahan Bungus Barat and farmer group of Sakato Kelurahan Lambung Bukit, Padang City. The training aimed to show to farmers the predation rate of both predators against ten individuals of BPH provided. The treatment consisted of the predation rate of both predators (1 individual of wolf spider, 1 individual of lady beetle, 1: 3 composition of the joint predator) in 3 replications. All wolf spiders, lady beetles and BPH used were collected from rice field in Pauh District, Padang City. Within one hour, joint predators in Rambutan were able to consume 53\% of the BPH provided, while joint predators in Sakato were able to consume 43\%. Some efforts from farmers are needed to protect and conserve the presence of two predators so that they can act as natural enemies in the field.
\end{abstract}

\section{ABSTRAK}

Serangan wereng batang coklat atau WBC (Nilaparvata lugens) di Sumatra Barat telah tercatat sejak tahun 2012, dan terus mengalami peningkatan sepanjang tahun 2015-2017. Laba-laba serigala (Pardosa pseudoannulata) dan kumbang bemo (Verania lineata) adalah dua jenis predator yang dapat dimanfaatkan untuk menjadi pengendali alami. Beberapa laporan penelitian sebelumnya menyebutkan bahwa laba-laba serigala mampu memangsa WBC sebanyak 5-15 ekor per hari sedangkan kumbang bemo memangsa sebanyak 1-11 ekor. Pelatihan ini telah dilaksanakan di Keltan Rambutan, Kel. Bungus Barat dan Keltan Sakato Kel. Lambung Bukit Kota Padang. Tujuannya adalah memperlihatkan kepada petani kemampuan memangsa kedua jenis predator selama 1 jam terhadap 10 ekor WBC yang disediakan. Perlakuannya berupa kemampuan memangsa dua jenis predator (1 ekor laba-laba serigala, 1 ekor kumbang bemo, 1:3 joint predator) dalam 3 ulangan. Seluruh hewan uji (laba-laba serigala, kumbang bemo dan WBC) yang digunakan dikoleksi dari lahan persawahan Kecamatan Pauh. Hasil pengujian di Keltan Rambutan menunjukkan bahwa joint predator mampu memangsa 53\% WBC yang disediakan, sedangkan di Keltan Sakato mampu memangsa 43\% WBC dalam waktu satu jam. Diperlukan upaya dari petani untuk melindungi keberadaan predator tersebut sehingga mereka dapat berperan sebagai predator alami WBC di lapangan. 


\section{PENDAHULUAN}

Wereng batang coklat (Nilaparvata lugens) atau WBC merupakan hama utama pada tanaman padi, serangannya menyebabkan padi menjadi kuning kering dari kerusakan ringan sampai berat bahkan sampai gagal panen. Serangan tersebut dapat pula diikuti oleh serangan virus kerdil rumput dan kerdil hampa yang semakin memperparah tingkat serangan (Baehaki, 2011). Serangan WBC di Sumatera Barat telah tercatat sejak tahun 2012, dan terus mengalami peningkatan sepanjang tahun 2015-2017. Luas serangan pada tahun 2015 mencapai 550,71 ha dan pada tahun 2016 meningkat menjadi 865,93 ha, sedangkan pada tahun 2017 luas serangan menurun hingga 751,52 ha dan pada tahun 2018 menjadi 440,45 ha (BPTPH, 2019).

WBC memiliki keunggulan karena berkembang biak dengan cepat, cepat menyebar dan menemukan habitat baru, mudah beradaptasi dengan varietas tahan dengan membentuk biotipe baru dan mudah resisten terhadap insektisida (Baehaki, 2011). Pada saat ini, WBC masih sangat ditakuti oleh petani dan petugas lapangan karena serangannya tidak bisa diprediksi dan sewaktu-waktu dapat menyerang dan menggagalkan hasil panen. Rasa kekhawatiran inilah yang mendorong petani untuk masih melakukan penyemprotan sawah mereka secara preventif dengan berbagai jenis pestisida yang mereka anggap efektif termasuk pestisida yang dilarang menurut Inpres 3/1986 (Untung, 1995).

Faktor pemicu terjadinya serangan WBC utamanya disebabkan oleh budidaya konvensional yang mengandalkan varietas unggul, pupuk dan budidaya tanpa rotasi tanaman. Aplikasi pestisida yang tidak sesuai dengan kaidah yang ada, seperti melakukan penyemprotan secara berlebihan, menggunakan pestisida yang dilarang pemerintah bisa menyebabkan WBC menjadi resisten sehingga terjadi ledakan WBC, hal tersebut terjadi pada daerah yang kami kunjungi.

Teknik pengendalian yang kami sosialisasikan pada pengabdian masyarakat ini adalah pemangsaan musuh alami dengan menggunakan predator yaitu Pardosa pseudoannulata atau laba-laba serigala dan Verania lineata yang biasa disebut dengan kumbang bemo. Laba-laba serigala dan kumbang bemo adalah dua jenis predator yang sering ditemukan berada di sekitar persawahan secara bersamaan dan dapat dimanfaatkan untuk menjadi pengendali alami.

Berdasarkan hasil penelitian, laba-laba serigala secara tunggal mampu memangsa WBC sebanyak 5-15 ekor per hari (Shepard et al., 1987; Heong et al., 1990; Lubis, 2005; Syahrawati et al., 2015) sedangkan kumbang bemo memangsa sebanyak 1-11 ekor per hari (Miranti et al., 2000; Lubis, 2005; Karindah, 2011; Syahrawati et al., 2015). Keberadaan keduanya secara bersamaan (joint predator) dapat menyebabkan adanya kompetisi akan tetapi masih dapat menekan populasi tinggi WBC mencapai 80\%. Penelitian terbaru Syahrawati et al. (2019) telah menemukan komposisi joint predator yang aman pada satu rumpun padi dengan perbandingan 1:3 ekor, yakni 1 ekor laba-laba serigala dan 3 ekor kumbang bemo. Hal ini untuk menghindari kompetisi dan kanibalisme yang terjadi antar laba-laba serigala. Petani diharapkan dapat memonitor keberadaan predator ini di lapangan, dan bersedia melakukan konservasi terhadap kedua predator tersebut karena terbukti mampu mengendalikan laju populasi WBC dengan aman tanpa meracuni lingkungan sekitar.

Kelompok Tani Rambutan adalah salah satu kelompok tani di Kelurahan Bungus Barat, Kecamatan Bungus Teluk Kabung yang beranggotakan sekitar 50 orang petani pemilik lahan, dengan luas lahan per anggota berkisar antara 0,5 - 2,0 ha. Keltan ini berjarak sekitar 29,9 km dari Fakultas Pertanian Unand. Sistem budidaya yang digunakan masih konvensional yakni menggunakan pupuk urea, TSP, dan NPK serta mengendalikan hama umumnya menggunakan pestisida sintetik. Varietas padi andalan petani dominannya adalah IR 42, sesekali diselingi dengan Anak Daro dan Cantik Manih. Kondisi ini diperkirakan dapat menjadi penunjang pesatnya perkembangan wereng batang coklat ketika kondisi lingkungan memungkinkan. 
Berdasarkan kunjungan lapangan yang dilakukan, terdapat spot-spot serangan WBC di lahan anggota kelompok tani tersebut.

Sementara itu, berdasarkan informasi dari pengamat hama penyakit (PHP) Kota Padang, ada beberapa lokasi yang cukup parah terserang WBC salah satunya adalah lahan milik petani yang tergabung dalam kelompok Keltan Sakato, Kelurahan Lambung Bukik Kecamatan Pauh. Lokasi ini berjarak sekitar 6 km dari Fakultas Pertanian. Anggota kelompok tani sekitar 60 orang, yang mengolah lahan sekitar 0,5 ha per anggota. Sistem budidaya yang dilakukan juga masih konvensional yakni menggunakan varietas IR 42, pupuk dan pestisida sintetik. Berbeda halnya dengan Keltan Rambutan yang cukup rutin melakukan pertemuan, Keltan Sakato jarang melakukan pertemuan kelompok (Gambar 1).
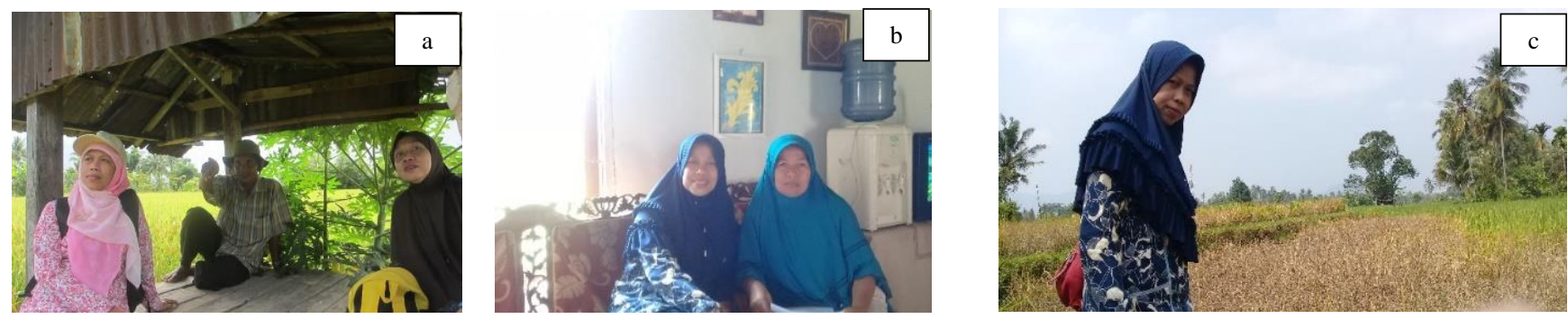

Gambar 1. Kunjungan lapangan. a. Diskusi dengan Ketua Keltan Rambutan, b, Diskusi dengan salah seorang anggota Keltan Sakato, c. lahan terserang WBC di Keltan Sakato

Meskipun dengan intensitas serangan berbeda, ternyata kedua lokasi sama-sama memiliki spot serangan WBC. Adanya spot serangan tersebut, selanjutnya akan menjadi penyuplai utama serangan WBC di beberapa lokasi. Budidaya padi sawah konvensional adalah pemicu utama terjadinya ledakan populasi WBC di beberapa tempat, selain adanya pengaruh faktor iklim. Tujuan pengabdian ini adalah pelatihan seputar Pemangsaan Wereng Batang Coklat (WBC) menggunakan joint predator kepada petani berdasarkan hasil penelitian dan mengarahkan petani untuk melakukan konservasi musuh alami seperti predator.

\section{METODE}

\section{Pelaksanaan}

Kegiatan pelatihan tersebut sudah dilaksanakan oleh 6 orang tim Pengabdi LPPM Unand yang berasal dari Prodi Proteksi Tanaman dengan berbagai bidang keahlian, serta didukung oleh 8 orang mahasiswa peneliti WBC Fakultas Pertanian Unand. Sasaran dalam kegiatan ini adalah Kelompok tani Rambutan, Kel. Bungus Barat dan Kelompok tani Sakato Kel. Lambung Bukit Kota Padang. Salah satu materi pelatihan adalah sosialisasi pemangsaan joint predator yang sering ditemukan di persawahan, materi ini langsung diberikan oleh Dr. My Syahrawati selaku ketua pelaksana pengabdian.

Diakhir pemberian materi diikuti dengan praktek pemangsaan dalam bentuk pengujian. Pengujian ini untuk memperlihatkan kepada petani kemampuan memangsa kedua jenis predator selama 1 jam terhadap 10 ekor WBC yang disediakan. Pengujian berupa kemampuan memangsa dua jenis predator (1 ekor laba-laba serigala, 1 ekor kumbang bemo, joint predator 1:3) dalam 3 kali ulangan. Seluruh hewan uji yang digunakan merupakan populasi lapangan dari lahan persawahan Kecamatan Pauh (Gambar 2), yakni Laba-laba Serigala (a), Kumbang bemo (b), dan Wereng batang coklat (c). 

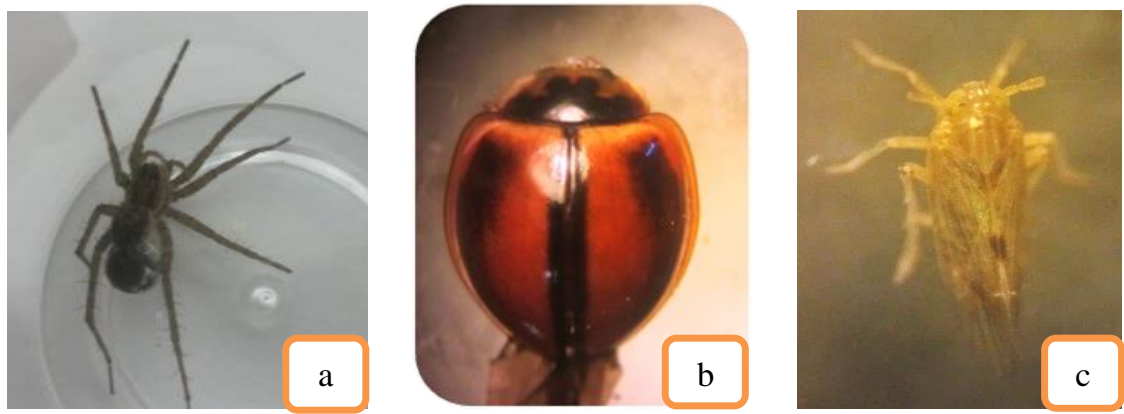

Gambar 2. Hewan yang digunakan untuk uji pemangsaan

\section{Pengujian}

Pengujian di Keltan Rambutan dilaksanakan pada hari Jumat tanggal 01 November 2019 di Mushala Nurul Shadiqin, sedangkan pengujian di Keltan Sakato dilakukan pada hari Minggu tanggal 09 November 2019 di Mushalla Nurul Mukmin. WBC yang dikoleksi kemudian langsung dipelihara dalam stoples yang telah berisi bibit padi. Adapun predator yang dikoleksi dimasukkan ke dalam gelas mineral yang telah berisi 3 ekor WBC secara terpisah selama 1 jam, untuk selanjutnya dilaparkan selama 24 jam. Uji pemangsaan dilaksanakan di lokasi pengabdian dengan disaksikan para peserta saat penyampaian materi, dan hasil akhir diumumkan sebelum acara penutupan (Gambar 3). Data yang diperoleh dirata-ratakan dan ditampilkan dalam bentuk grafik batang (Gambar 4).
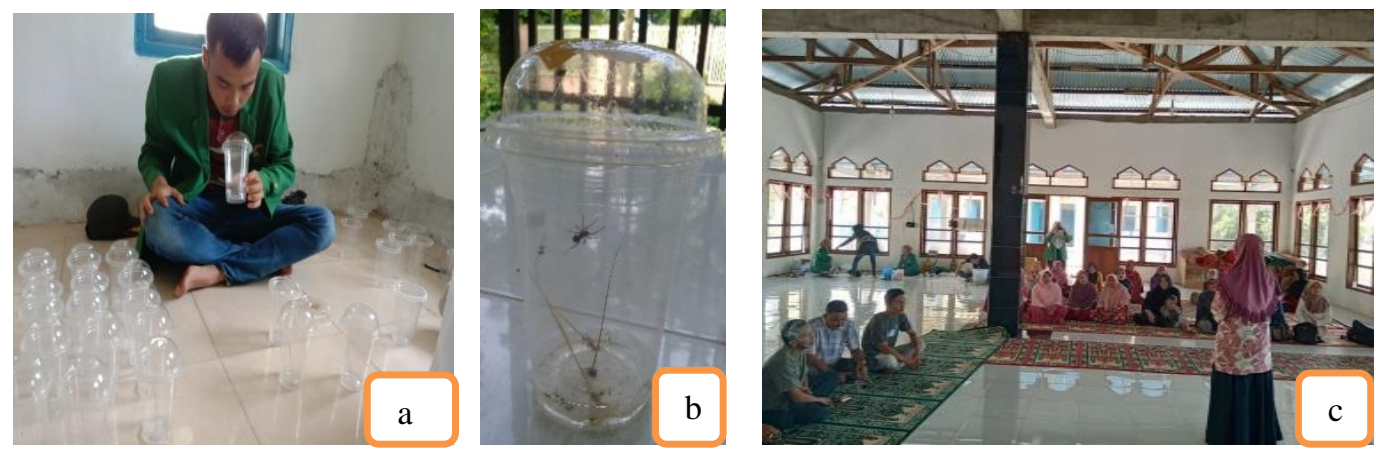

Gambar 3. Pelaksanaan: a. Persiapan pengujian, b. Predator uji sesuai perlakuan dimasukkan ke dalam media pengujian berupa gelas plastik yang diisi 3 batang bibit padi dan 10 ekor WBC, c. Sosialisasi predator dan tingkat pemangsaan kepada petani
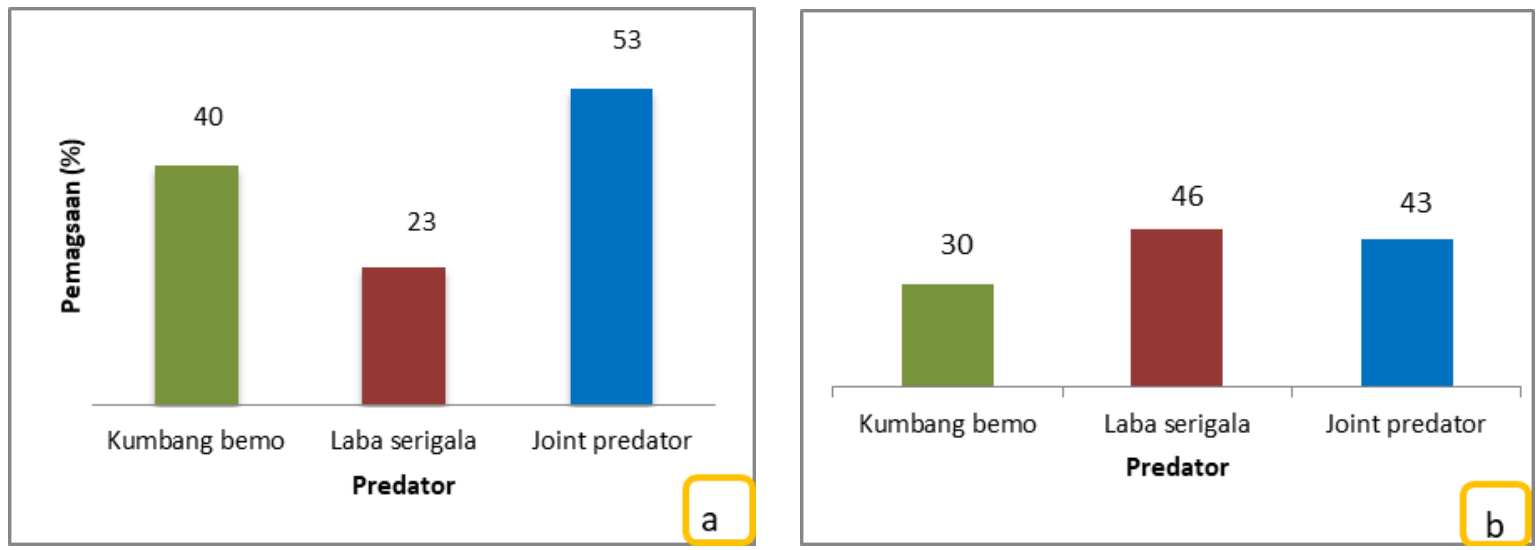

Gambar 4. Persentase pemangsaan wereng batang coklat oleh predator kumbang bemo, labalaba serigala dan joint predator selama satu jam pengamatan, a. Keltan Rambutan, b. Keltan Sakato 


\section{HASIL DAN PEMBAHASAN}

\section{Peserta}

Jumlah peserta yang mengikuti pelatihan PHT Wereng Batang Coklat di Keltan Rambutan sebanyak 22 orang, sedangkan di Keltan Sakato sebanyak 24 orang. Tingkat partisipasi peserta pada setiap tahapan kegiatan rata-rata diatas 85\%. Sepanjang kegiatan berlangsung, ada pengakuan peserta bahwa bahwa mereka tidak mengetahui persis perbedaan serangga hama dan predator yang ada di persawahan mereka, dan berkeinginan untuk melakukan perubahan teknik pengendalian yaitu diawali dengan monitoring keberadaan hama dan predator sebelum memutuskan teknik pengendalian.

\section{Persentase Pemangsaan Predator}

Ada perbedaan presentase pemangsaan predator pada dua tempat pengujian. Persentase pemangsaan joint predator selama 1 jam pengamatan di Keltan Rambutan adalah 53\% dan persentase pemangsaan joint predator di Keltan Sakato 43\%. Pemangsaan secara tunggal lebih rendah dibandingkan dengan joint predator dan pemangsaan laba-laba serigala lebih tinggi daripada kumbang bemo. Pengujian di Keltan Rambutan, persentase pemangsaan laba-laba serigala secara tunggal adalah $40 \%$ dan kumbang bemo 23\%. Adapun pengujian pada Keltan Sakato, persentase pemangsaan secara tunggal laba serigala 46\% dan kumbang bemo $30 \%$. (Gambar 4).

Hasil pengujian telah disampaikan kepada petani diakhir kegiatan bahwa jumlah pemangsaan dan persentase pemangsaan joint predator dan predator tunggal bervariasi di kedua lokasi. Tinggi rendahnya pemangsaan antara lain dipengaruhi oleh perilaku memangsa, kemampuan memangsa dan tingkat kelaparan. Keberadaan joint predator di lahan persawahan tidak menjamin tingginya pemangsaan terhadap WBC, akan tetapi secara pasti dapat menekan populasi WBC di lapangan mencapai 53\%. Oleh sebab itu, konservasi keberadaan predator sangat penting dilakukan pada ekosistem sawah sehingga bisa terjadi pengendalian WBC secara alami dan agar petani dapat mengurangi input insektisida sintetik pada kondisi ditemukan kehadiran predator tersebut di lahan persawahan.

Para peserta mengikuti pemberian materi dengan baik, dari awal sampai akhir acara, dan dapat memahami pentingnya konservasi predator tersebut. Hal ini dapat dilihat dari antusias petani dalam mendengarkan dan mendiskusikan permasalahan yang di alami kepada tim pengabdi. Petani jadi lebih memahami dalam membedakan serangga yang baik untuk membantu tanaman padi dan serangga yang menjadi hama pada tanaman padi mereka. Petani juga dibekali cara perawatan dan cara penyemprotan yang baik sehingga bisa mengetahui cara mengendalikan hama yang merusak tanaman padi mereka tanpa harus membunuh musuh alami yang ada pada tanaman padi tersebut yang juga berperan sebagai pengendali hayati untuk pengendali hama wereng batang coklat (WBC).

Dengan adanya pelatihan ini petani di harapkan sudah mampu memonitor keberadaan predator ini di lapangan, dan menambah pengetahuan petani tentang pentingnya menjaga keberadaan predator ini dilapangan sehingga bersedia melakukan konservasi terhadap kedua predator tersebut karena terbukti mampu mengendalikan laju populasi WBC dengan aman tanpa meracuni lingkungan sekitar dan serangan WBC pada wilayah tersebut dapat berkurang.

\section{KESIMPULAN}

Pemangsaan joint predator dan predator tunggal bervariasi di dua lokasi pengabdian. Hasil pengujian di Keltan Rambutan menunjukkan bahwa joint predator mampu memangsa 53\% WBC 
yang disediakan, sedangkan di Keltan Sakato mampu memangsa 43\% WBC dalam waktu satu jam. Penulis menyarankan petani bahwa perlu melindungi keberadaan predator tersebut sehingga mereka dapat berperan sebagai predator alami WBC di lapangan. Dari hasil yang didapat dalam pelaksanaan, disarankan agar penyuluhan dan pelatihan semacam ini dapat terus berlanjut atau dilakukan dalam waktu yang lebih intensif sehingga petani betul-betul dapat dibimbing sampai mandiri dan dilakukan evaluasi setelah beberapa bulan kegiatan untuk melihat apakah petani sudah menerapkan ilmu yang diberikan dengan baik.

\section{UCAPAN TERIMA KASIH}

Terima kasih kami ucapkan kepada Lembaga Pengabdian Kepada Masyarakat Universitas Andalas yang telah menyediakan dana pengabdian Skim IbDM sesuai kontrak nomor: T/75/UN.16.17/PM.IbDM/LPPM/2019 atas nama My Syahrawati. Ucapan terima kasih juga disampaikan kepada Ketua Keltan Rambutan Kel. Bungus Barat, Ketua Keltan Sakato Kel. Lambung Bukit dan para anggota yang telah bekerjasama dan berpartisipasi dalam pelaksanaan pengabdian ini.

\section{DAFTAR PUSTAKA}

Baehaki SE. 2011. Strategi fundamental pengendalian hama wereng batang coklat dalam pengamanan. Pengembangan Inovasi Pertanian. 4(1): 15-16.

BPTPH Sumatera Barat. 2019. Laporan evaluasi luas serangan OPT padi di Sumatera Barat tahun 2015-2018. Balai Perlindungan Tanaman Pangan dan Hortikulutura Sumatra Barat. Padang.

Heong Kl, S Bleih, EG Rubia. 1990. Prey preference of the wolf spider, Pardosa pseudoannulata (Boesenberg et Strand). Population Ecology 33(2): 179-186.

Karindah S. 2011. Predation of five generalist predators on brown planthopper (Nilaparvata lugens Stål). Entomologi Indonesia 8 (2): 55-62.

Lubis Y. 2005. Peranan keanekaragaman hayati artropoda sebagai musuh alami pada ekosistem padi sawah. Jurnal Pertanian Bidang Ilmu Pertanian 3 (3): 16-24.

Miranti AH, D Pratiwi dan S Jauhari. 2000. Evaluasi introduksi teknologi pengendalian wereng cokelat pada periode pasca SUP padi di Kabupaten Sragen. Makalah Seminar. BPTP Ungaran.

Shepard BM, AT Barrion dan JA Litsinger. 1987. Friends of the rice farmer: Helpful insects, spiders \& pathogens. IRRI. Los Banos.

Syahrawati M, E Martono, NS Putra, dan BH Purwanto. 2015. Predation and competition of two predators (Pardosa pseudoannulata and Verania lineata) on different densities of Nilaparvata lugens in Laboratory. International Journal of Science and Research (IJSR). 4(6): 610-614. 
Syahrawati M, S Desiska, and Arneti. 2019. Effect of joint predators (Pardosa Pseudoannulata and Verania lineata) on Nilaparvata lugens in competitive condition. Draft for publication in Journal of Crop Protection.

Untung K. 1995. Fluktuasi popuasi wereng batang coklat (Nilaparvata lugens stal) di Kalitro Yogyakarta selama 10 musim padi. Jurnal Perlindungan Tanaman Indonesia 1(1): 12-18. 